\title{
Implementasi Pojok Baca untuk Meningkatkan Minat Baca Siswa MI Muhammadiyah Kartasura
}

\author{
Wahyu Kurniawan ${ }^{1}$, Anam Sutopo ${ }^{2}$, Minsih ${ }^{3}$ \\ Magister Pendidikan Dasar, Sekolah Pascasarjana, Universitas Muhammadiyah Surakarta, Surakarta, \\ Indonesia \\ Email: ${ }^{1}$ wahyukurniawan.mimpkkts@gmail.com, ${ }^{2}$ anam.sutopo@ums.ac.id, ${ }^{3}$ min $139 @$ ums.ac.id
}

\begin{abstract}
This research aims to illustrate the implementation of the reading corner to increase the interest in reading the MI Muhammadiyah Kartasura students. The study uses a qualitative inductive approach. Data and collection techniques consist of primary data and secondary data obtained through observations, interviews, polls or questionnaires and documentation. Data validation uses the theory and techniques of the source triangulation and triangulation method. Data analysis uses interactive models including data collection, data reduction, data presentation and withdrawal of conclusions. Results from the study showed that. 1) The implementation of reading corners can increase student interest in the school environment with habituation, learning, development and school programs for students to read. 2) Student reading interest increases with a reading corner that encourages students to better appreciate their time reading books in the classroom reading corner. 3) The implementation of this reading corner is effective enough to increase the interest of reading students in the school environment and facilitate teachers to implement and relate lessons to create varied learning.
\end{abstract}

Keywords: reading, implementation, interests, corner, student

\begin{abstract}
Abstrak
Penelitian ini bertujuan untuk menggambarkan implementasi pojok baca untuk meningkatkan minat baca siswa MI Muhammadiyah PK Kartasura. Penelitian ini menggunakan pendekatan kualitatif induktif. Teknik data dan pengumpulan terdiri dari data primer dan data sekunder yang diperoleh melalui observasi, wawancara, angket atau kuesioner dan dokumentasi. Data validasi menggunakan teori dan teknik triangulasi sumber dan triangulasi metode. Analisis data menggunakan model interaktif termasuk pengumpulan data, reduksi data, penyajian data dan penarikan kesimpulan. Hasil dari penelitian menunjukkan bahwa 1) implementasi pojok baca dapat meningkatkan minat baca siswa di lingkungan sekolah dengan pembiasaan, pembelajaran, pengembangan dan program sekolah untuk siswa membaca. 2) minat baca siswa meningkat dengan adanya pojok baca yang mendorong siswa untuk lebih menghargai waktunya untuk membaca buku di pojok baca kelas. 3) implementasi pojok baca ini cukup efektif untuk meningkatkan minat baca siswa di lingkungan sekolah dan memudahkan guru dalam menerapkan dan mengkaitkan pelajaran untuk mencipkatan pembelajaran yang bervariatif.
\end{abstract}

Kata Kunci: baca, implementasi, minat, pojok, siswa

\section{A. PENDAhuluan}

Masa jenjang sekolah dasar merupakan masa yang penting dalam pertumbuhan dan perkembangan anak. Pada usia inilah, masa yang tepat untuk menanamkan kebiasaan-kebiasaan baik pada anak. Apabila ditanamkan sejak dini, maka kebiasaan baik tersebut akan melekat pada anak hingga usia dewasa. Kebiasaan-kebiasaan kecil seperti membaca dapat dimulai sejak dini. Membaca merupakan hal yang sangat penting dalam kehidupan. Semua proses belajar didasarkan atas dasar kemampuan membaca. Di Indonesia, rendahnya membaca menyebabkan sumber daya menusianya tidak kooperatif sebagai akibat lemahnya minat membaca. Mullis (2012) menerangkan bahwa data PIRLS (Progress International reading Literasi Study) tahun 2011 dalam uji literasi membaca dalam mengukur aspek memahami, menggunakan dan merefleksi hasil membaca dalam bentuk tulisan Indonesia menduduki urutan ke 45 dari 48 negara peserta dengan memperoleh skor 428 dari rata-rat skor 500. Keterpurukan hasil tersebut diperkuat dengan 
uji literasi membaca dalam PISA (Program for International Student Assesment) pada tahun 2009 yang menunjukkan peserta didik Indonesia berada pada peringkat ke 57 dari 65 peserta dengan memperoleh skor 396 dari rata-rata skor 493, sedangkan pada tahun 2012 peringkat Indonesia semakin menurun pada peringkat ke 64 dari 65 peserta dengan skor 396 dari rata-rata skor 496 (OECD, 2014). Wiedarti (2016) menjelaskan bahwa data tersebut selaras dengan penemuan UNESCO, dimana kebiasaan membaca masyarakat Indonesia berada dalam ketegori rendah dan hanya satu dari seribu orang masyarakat Indonesia yang membaca.

Kementerian Pendidikan dan Kebudayaan (Kemendikbud) tahun 2016 terus mengupayakan budaya membaca untuk masyarakat Indonesia, khususnya untuk anak-anak usia sekolah dasar. Slaah satu trobosan yang dilakukan pemerintah dalam Peraturan Menteri Pendidikan dan Kebudayaan (Permendikbud) nomor 23 tahun 2015 tentang penumbuhan budi pekerti pada anak dengan mengembangkan gerakan literasi sekolah. Retnaningdyah (2016) menjelaskan juga bahwa literasi sekolah adalah kegiatan peserta didik untuk menciptakan masyarakat gemar membaca, menulis, menyimak dan berpikir kritis berdasarkan tahapan pembiasaan, pengembangan dan pembelajaran. Gerakan literasi sekolah tersebut merupakan upaya secara menyeluruh yang melibatkan seluruh warga sekolah baik guru, siswa, pustakawan, orang tua dan masyarakat sebagai bagian dari ekosistem pendidikan. Pemerintah melalui instansi-instansi terkait dan berbagai lembaga swadaya masyarakat berusaha mengadakan program-program yang bertujuan untuk menumbuhkan minat baca anak, misalnya dengan membuat perpustakaan keliling dan taman baca. Pada awalnya, program ini berjalan dan mampu menarik perhatian anak-anak khususnya usia sekolah dasar menjadi gemar untuk membaca. Tetapi, program tersebut bersifat tidak permanen. Seiring dengan meredanya program tersebut, kegemaran anak dalam membaca juga ikut mereda.

Keterlibatan sekolah dalam hal ini, sangatlah penting dalam pelaksanaan suatu program yang telah dilakukan sebelumnya dalam menumbuhkan minat baca anak di lingkungan sekolah dasar, selain untuk meningkatkan pembelajaran dapat juga meningkatkan minat baca anak. Sehingga proses pembeajaran akan menjadi lebih bermakna, bermutu dan menyenangkan. Dalam mewujudkan hal tersebut, tentunya pihak sekolah dapat memfasilitasinya, salah satunya dengan cara membuat pojok baca pada tiap-tiap kelas di jenjang sekolah dasar. Seperti halnya pojok baca yang tersedia di Madrasah Ibtidaiyah Muhammadiyah Kartasura.
Realita yang ada di MI Muhammadiyah Kartasura telah disediakan pojok baca untuk kegiatan membaca anak di kelas, tetapi keberadaan pojok baca anak di kelas ini, belum sepenuhnya dioptimalkan oleh siswa. Banyak siswa yang malas untuk membaca. Siswa cenderung tidak ada minat dan motivasi untuk membaca buku, baik buku pelajaran maupun buku bacaan pengetahuan umum. Selain itu, siswa jarang memanfaatkan waktunya untuk membaca dipojok baca yang ada di kelas, siswa lebih senang menghabiskan waktunya untuk bermain dengan teman, siswa sering menganggap pojok baca hanya sebagai pajangan buku saja di kelas, siswa juga kurang percaya diri untuk bergabung dengan teman yang sudah lancar membaca, kurangnya bahan pustaka buku dan kurangnya kegiatan yang dapat menunjang siswa untuk giat membaca. Rendahnya minat baca siswa inilah, disebabkan salah satunya karena kurangnya implementasi pojok baca. Padahal, pada dasarnya dengan ada dan disediakannya pojok baca diharapan dapat meningkatkan minat baca siswa. Peran pihak sekolah baik kepala sekolah, guru, pustakawan dan orang tua sangat diperlukan sebagai pembimbingan siswa dalam mengimplementasikan pojok baca agar lebih memberikan pengetahuan dan pemahaman untuk siswa pentingnya membaca. Oleh karena itu, "implementasi pojok baca untuk meningkatkan minat baca siswa MI Muhammadiyah Kartasura tahun pelajaran 2019/2020" sangat penting untuk diungkap sebagai program dan pembiasaan baik di tiap-tiap kelas, karena dipandang berbeda dengan implementasi pojok baca untuk meningkatkan literasi siswa dijenjang sekolah dasar formal pada umumnya.

\section{B. PELAKSAAAN DAN METODE}

Penelitian ini menggunakan jenis dan desain penelitian kualitatif induktif. Arifin (2012: 140) menjelaskan penelitian kualitatif adalah suatu proses penelitian yang dilakukan secara wajar dan natural sesuai dengan kondisi objektif di lapangan tanpa adanya manipulasi serta jenis data yang dikumpulkan terutama data kualitatif. Penelitian ini menggunakan pendekatan induktif. Sugiyono (2015: 8-9) menjelasakn bahwa metode penelitian kualitatif adalah metode penelitian yang berlandasakan padafilsafat post posititivisme, digunakan untuk meneliti pada kondisi objek alamiah (sebagai lawannya adalah eksperimen) dimana peneliti adalah sebagai instrumen kunci, teknik pengumpulan data dilakukan secara triangulasi (gabungan), analisi data bersifat induktif kualitatif dan hasil penelitian kualitatif lebih menekankan makna dari pada generalisasi. Senada dengan Mahmud (2011: 95) menjelaskan bahwa desain peneliian (research design) adalah suatu rencana untuk memilih subjek untuk menjawab pertanyaan penelitian dengan 
kredibilitas mengacu pada seberapa luar hasilnya mendekati realitas dan dipertimbangkan sebagai sesuatu yang dapat dipercaya dan masuk akal. Penelitian ini memfokuskan peran kepala sekolah, guru, pustakawan, orang tua dan siswa.

Tahapan lekasanaan penelitian mulai dari persiapan sampai dengan penulisan laporan penyelesaian secara keseluruhan dilaksanakan selama empat bulan, mulai bulan Juli 2020 sampai bulan Oktober 2020. Data dan sumber data dalam penelitian ini berupa peran kepala sekolah, guru, pustakawan dan siswa dalam implementasi pojok baca. Data dalam penelitian ini yaitu data primer yang dikumpulkan peneliti memalui informan dan data sekunder digunakan peneliti untuk memperoleh sumber dari dokumen-dokuemn, buku dan jurnal. Sumber data dalam penelitian kualitatif ini adalah kata-kata dan tindakan selebihnya adalah tambahan. Kehadiran peneliti dalam penelitian ini adalah sebagai instrumen kunci (key instrument) yang secara langsung melibatkan diri dalam proses pengumpulan data penelitian sebagai perencana, pelaksana dan analisis serta pelopor hasil penelitian.

Teknik pengumpulan data adalah cara peneliti dalam membuat gambaran awal yang dilakukan dalam kondisi yang alami dalam pengumpulan data. Teknik pengumpulan data dalam penelitian ini menggunakan teknik observasi, wawancara, angket atau kuesioner dan dokumentasi. Sugiyono (2015: 401-402) menjelaskan bahwa penelitian ini keabsahan datanya menggunakan rencana dalam uji kredibilitasnya dengan menggunakan triangulasi. Triangulasi dalam penelitain ini menggunakan triangulasi sumber sebagai pembanding data dalam pengecekan derajat kepercayaan suatu informasi yang diperoleh melalui waktu dan alat yang berbeda dalam penelitian kualitatif dengan menggunakan data primer dalam mencari kdata berupa kata-kata dan tindakan hasil wawancara dan observasi kepada kepala sekolah, guru, pustakawan dan siswa dan triangulasi metode sebagai pengecekan derajat kepercayaan penemuan hasil penelitian dengan beberapa teknik pengumpulan data dan pengecekan derajat kepercayaan beberapa sumber data dengan metode yang sama untuk mencari tambaan data berupa perilaku dan karakteristik siswa dalam kelas.. Sugiyono (2015: 337) menjelaskan juga bahwa teknik analisis data kualitatif secara interaktif dan berlangsung secara tuntas mulai reduksi data (data reduction) dalam prosesnya merujuk pada pemilihan, pemfokusan, penyederhanaan dan abstraksi data berupa catatancatatan secara tertulis yang terjadi secara kontinu dan kualitatif, penyajian data (data display) dalam prosesnya berupa narasi, uranian singkat, bagan, hubungan antar kategori dan flowchart dan penarikan kesimpulan dan verifikasi (conclusion drawing and verification) dalam prosesnya peneliti menarik keseimpulan yang beraitan dengan datadata yang diperlukan secara jelas dan jujur. Akan tetapi, apabila terjadi ketidaksesuaian penarikan kesimpulan peneliti akan memverifikasi data pada reduksi data yang akan disajikan.

\section{HASIL DAN PEMBAHASAN}

Kemendikbud (2016: 17) menjelaskan bahwa pojok baca merupakan sebuah ruangan yang terletak disudut kelas yang dilengkapi dengan koleksi buku-buku dan berperan sebagai perpanjangan fungsi perpustakaan. Senada dengan Faradina (2017: 61) menjelaskan bahwa sudut baca merupakan perpanjangan fungsi perpustakaan sekolah dasar yaitu untuk mendekatkan buku pada siswa, buku yang tersedia di sudut baca berasal dari perpustakaan sekolah selain itu siswa wajib membawa buku dari rumah utuk diletakkan di sudut baca kelas utuk dikelola guru, pustakawan dan siswa. Tujuan pojok baca digunakan untuk meningkatkan minat baca siswa yang dilengkapi dengan beberapa bahan pustaka degan tujuan untuk mengenalkan pada siswa beragam sumber bacaan untuk dimanfaatkan sebagai media, sumber belajar yang memberikan pengelaman membaca yang menyenangkan (Kemendikbud, 2016: 13).

Priyatni (2017: 157) juga menjelaskan bahwa literasi adalah sebagai keberaksaraan atau melek aksarayang fokus utamanya pada kemampuan membaca, kemampuan menulis dan kemampuan numerik. Senada dengan hal itu, Widyaningrum (2016: 128-132) juga menjelaskan bahwa literasi adalah penggunaan praktik-praktik situsional dan historis serta kultural dalam menciptakan dan menginterprestasikan makna melalui teks. Dalam literasi tetunya mencakup konsep dan tujuan literasi. Menurut Haryatni (2018: 1-10) menyebutkan bahwa konsep literasi yaitu literasi dasar yang berkaitan dengan pengembangngan kegiatan membaca, menulis dan berhitung, literasi perpustakaan yang berkaitan dengan menggalakkan kegiatan literasi dengan menggunakan referensi yang ada di perpustakaan, literasi teknologi yang berkaitan dengan penggunaan kemajuan teknologi untuk memudahkan kegiatan literasi, literasi media yang berkaitan dengan penggunaan media sebagai promosi literasi dan literasi visual yang berkaitan dengan kemampuan untuk mengapresiasikan design grafis dan teks visual. Wandasira (2017: 326) menyebutkan bahwa tujuan literasi yaitu menumbuh kembangkan budaya literasi di sekolah, meningkatkan kapasitas warga dan lingkungan sekolah agar literat, menjadikan sekolah sebagai taman belajar yang menyenangkan dan ramah anak agar warga sekolah mampu mengelola pengetahuan dan menjaga keberlanjutan 
pembelajaran dengan menghadirkan beragam buku bacaan dan mewadahi berbagai strategi membaca.

Rendahnya literasi disebabkan beberapa faktor yaitu minimnya tempat untuk melakukan aktivitas baca yang mudah dan terjangkau, rendahnya minat membaca baik dari siswa maupun gurunya, kurangnya pendampingan guru pada siswa dalam berliterasi dan tidak optimalnya apresiasi dan penilaian guru pada siswa dalam meningkatkan ketrampilannya dalam membaca dan tidak adanya evaluasi terhadap pelaksanaan program kegiatan yang lebih baik. Menurut Hartono (2016: 282) mengemukakak bahwa faktor penyebab rendahnya membaca yaitu kurikulum pendidikan dan sistem pembelajara yang belum mendukung pada peserta didik, masih banyaknya jenis hiburan, permaianan game dan tayangan televisi yang tidak mendidik, kebiasaan masyarakat terdahulu yang telah turun temurun seperti kebiasaan mendongeng dan bercerita, rendahnya produksi buku-buku tang berkualitas dan masih adanya kesenjangan penyebaran buku di kelas, rendahnya dukungan dari pihak keluarga yang keseharian disibukkan dengan kegiatan-kegiatan keluarga yang menyentuh aspek-aspek penumbuhan minat baca anak dan minimnya sarana untuk memperoleh bahan bacaan seperti buku teks.

Implementasi pojok baca untuk meningkatkan minat baca siswa dengan tiga tahapan yaitu tahap pembiasaan, pengembangan dan pembelajaran. Menurut Retnaningdyah (2016) menyebutkan bahwa pojok baca dalam meningkatkan minat baca ada beberapa tahapan yaitu tahap pembiasaan, siswa membutuhkan waktu 15 menit untuk membaca setiap hari, jurnal membaca harian, penataan sarana literasi, menciptakan lingkungan kaya teks dan memilih buku bacaan yang tujuannya untuk meningkatkan kemampuan memahami bacaan, meningkatkan rasa cinta terhadap membaca diluar jam pelajaran dan siswa mampu menumbuhkan dan mengembangkan berbagai macam sumber bacaan yang membentuk rasa percaya diri anak sebagai pembaca yang baik. Tahap pengembangan adalah membutuhkan waktu 15 menit membaca setia harinya, jam membaca mandiri untuk kegiatan kulikuler/ko-kulikuler, menaggapi bacaab secara lisan dan tulisan yang tujuannya untuk membangun interaksi siswa, mengasah kemampuan siswa dalam buku, mengasah kemampuan siswa untuk berpikir kritis, analisis, kreatif, inovatif yang mendorong sisiwa untuk mencari keterkaitan antara buku yang dibaca pada dirinya sendiri dan lingkungannya. Tahap pembelajaran, pembelajaran 15 menit membaca, pemanfaatan berbagai strategi literasi dalam pembelajaran lintas disiplin yang tujuannya utnuk mengembangkan kemampuan siswa berpikir kritis, siswa mampu mengolah kemampuan komunikasi secara kreatif, siswa mampu mengembangkan kemampuan dalam memahami teks dan mengkaitkannya dengan pengalaman pribadi, memiliki kemampuan untuk menemukan informasi, mengevaluasi dan mampu mengeksploitasi informasi untuk mengambil berbagai keputusan yang tepat sasaran.

Kemendikbud (2016: 12) menyebutkan bahwa dalam pengelolaan program pojok baca di kelas merupakan tempat strategis dalam menempatkan bahan pustaka supaya lebih mendekatkan siswa pada buku, pengelolaan pojok baca di kelas yaitu Menyediakan sebagain area di dalam kelas untuk menyimpan koleksi bahan pustaka, merancang denah penempatan dengan memperhatikan pencahayaan, sirkulasi udara dan keamanan serta kenyamanan siswa, merancang model penataan koleksi bahan pustaka, menyediakan tempat atau rak koleksi bahan pustaka yang cukup, kuat dan aman, menentukan dan memilah penyediaan jenis koleksibahan pustaka yang ditempatkan di pojok baca sesuai degan minat dan jenjang kemampuan siswa, menyiapkan koleksi bahan pustakaan minimal sejumlah siswa di kelas, melengkapi koleksi bahan pustaka di pojok baca dari siswa dan kontribusi orang tua, menata koleksi bahan pustaka di kelas oleh guru dan siswa, menyiapkan buku rekap baca yang berisikan nama siswa dan judul buku, koleksi bahan pustaka sebaiknya diperbaharui untuk mempertahankan dan mengembangkan minat baca siswa selama satu bulan sekali dan tangung jawab pengelolaan pojok baca melibatkan guru dan siswa dalam kelas. Solusi dari kendala mengimplementasikan pojok baca untuk meningkatkan minat baca siswa. Menurut Hartono (2016: 284-286) menyebutkan bahwa ada tiga stakholder yang harus bekerjasama dalam meningkatkan literasi siswa sejak dini yaitu sekolah dalam hal pendanaan untuk koleksi bahan bacaan siswa, guru sebagai pelaksana pendidikan untuk lebih intensif dalam mendororng dan meningkatkan minat membaca siswa dan orang tua sebagai pihak yang paling bertanggung jawab terhadap masa depan siswa. Senada dengan hal tersebut, Sudarsana (2014: 429) menyebutkan bahwa pembinaan sistematis yaitu melalui program penumbuhan dan pengembangan minat baca di lingkungan keluarga, sekolah dan masyarakat sesuai dengan mencapai tujuan yang telah ditetapkan, mengatur pelaksanaan program penumbuhan dan pengembangan minat baca di lingkunga keluarga, sekolah dan masyarakat sesuai dengan pengaturan pelaksanaan program tersebut dengan pengorganisasian, mengendalikan pelaksanaan program penumbuhan dan pengembangan minat baca di lingkungan keluarga, sekolah dan masyarakat sesuai dengan pengendalian pengamatan terhadap seluruh kegiata pembinaan minat baca untu menjamin agar semua pekerjaan yang sedang dilakkukan tercapai dan menilai pelaksanaan program penumbuhan dan 
pengembangan minat baca siswa sesuai di lingkungan keluarga, sekolah dan masyarakat sesuai dengan pengolahan terakhir dalam organisasi. Penilaian dan evaluasi dalam pembianaan minat baca adalah proses pengukuran dan perbandinga hasil-hasil yang telah dicapai sesuai dengan rencana. Menumbuhkan dan meningkatkan minat baca siswa sejak dini di sekolah guru dapat mengajak siswa untuk membaca buku-buku yang menarik yang disukai melalui pojok baca di keas dengan memberikan tugas yang berkaitan dengan mencari simber bacaan yang tujuannya untuk merangsang anak untuk membaca di pojok baca di tiap-tiapkelas. Sekolaha dapat menumbuhkan minat bacasiswa khususnya di lingkunga sekolah dengan menjadikan pojok baca yang sifatnya aktifa dan kondusif. Pojok baca bisa juga mengadakan penjadwalan dimana ada kelompok baca, hari baca dan jam baca dalam seminggu yang semua koleksi bahan bacaan pojok baca disesuaikan dengan kubutuhan akan infromasi siswa dan usia anak sekolah dasar. Siswa usia sekolah dasar bahan bacaannya ringan yang hanya bertujuan untuk membangun dan meningkatkan minat baca yang diharapkan adanya koleksi buku-buku pelajaran dan juga buku-buku yang digemari siswa seperti halnya fiksi dan cerita rakyat yang bermuatan positif, menarik dan mendidik. Sehingga diharapkan siswa mempunyai alternatif bacaan buku pelajaran selain buku paket yang ada dipojok baca.

\section{PENUTUP}

\section{Simpulan}

Adanya implementasi pojok baca di lingkungan sekolah MI Muhammadiyah Kartasura inimerupakan hal baru atau mencari suasana baru dalam proses peningkatan minat baca siswa di sekolah karena pada dasarnya siswa harus mendapat dukungan untuk membaca dan membuat suasananya nyaman dalam proses peningkatan pengetahuan dan menambah wawasan. Pojok baca dikelola oleh guru dan siswa yang bertujuan untuk mengenalkan siswa pada sumber bacaan yang menyenangkan yang tentunya didukung dan bekerjasama dengan stakeholder yaitu dari pihak sekolah, guru sebagai pelaksana pendidikan dan lebih intensif dalam mendorong siswa untuk meningkatkan minat bacanya serta orang tua sebagai pihak yang paling bertanggung jawab dalam perkembangan membaca dan masa depan anak.

\section{Saran}

Saran dalam penelitian ini adalah perlu adanya fasilitas yang memadai terutama koleksi yang ada di pojok baca perlu adaya pembaharuan dan pengkoordinasian pojok baca di kelas-kelas da siswa sebagai pengelolaan dan penataan ahan bahan pustaka dipokok baca dan kemudian secara keseluruhan akan ditunjang dengan adnya program-program sekolah melalui pembiasaan, pengembangan dan pembelajaran, tentunya ini akan meningkatkan minat baca siswa MI Muhammadiyah Kartasura.

\section{E. DAFTAR PUSTAKA}

\section{(1) Standard artikel jurnal:}

Faradina, N. 2017. Pengaruh Program Geraan Literasi Sekolah terhadap Minat Baca Siswa di SD Islam Terpadu Muhammadiyah An -Najah Jatinom Klaten. Jurnal Hanata Widya Volume 6 Nomor 8, 61 .

Haryatni, M. S. 2018. Membangun budaya baca melalui pengelolaan media sudut baca kelas dengan "12345". Jurnal pemikiran dan pengembangan SD, Volume 6 Nomor 1 April, 111.

Wandasira, Y. 2017. Implementasi gerakan literasi sekolah (GLS) sebagai epmebntukan pendidikan berkarakter. Jurnal Manajemen, kepemimpinana dan supervisi pendidikan vol 1, no. 1, juliDesember, 326.

Widyaningrum, L. 2016. Membudayakan literasi berbasis manajemen sekolah (Aplikasi tantangan dan hambatan). jurnal dimas, 128-132.

(2) Bab dalam buku:

Kemendikbud. 2016. Panduan Pemanfaatan dan Pengembangan Sudut Baca Kelas dan Area Baca Sekolah untuk Meningkatkan Mutu Pembelajaran di Sekolah Dasar. Jakarta: Direktoral Jendral Pendidikan Dasar dan Menengah Kementerian Pendidikan dan Kebudayaan.

Mullis, I.V.S., Martin, M.O., Foy, P., \&Arora, A. 2012. TIMSS 2011 International Results In Mathematics. Chestnut Hill MA: TIMSS \& PIRLS International Study Center, Boston Collage.

Permendikbud Nomor 23. 2015. Penumbuhan Budi Pekerti. Jakarta: Direktoral Jendral Pendidikan Dasar dan Menengah Kementerian Pendidikan dan Kebudayaan.

Retnaningdyah, dkk. 2016. Gerakan Literasi Sekolah di Sekolah Menengah Pertama. Jakarta: Direktoral Jendral Pendidikan Dasar dan Menengah Kementerian Pendidikan dan Kebudayaan.

Wiedarti, P. 2016. Desain Induk Gerakan Literasi Sekolah. Jakarta: Direktoral Jendral Pendidikan Dasar dan Menengah Kementerian Pendidikan dan Kebudayaan 
(3) Buku, penulis personal:

Arifin, Zainal. 2012. Penelitian Pendidikan. Bandung: Remaja Rosdakarya.

Hartono. 2016. Manajemen Perpustakaan Sekolah. Yogyakarta: Ar-Ruzz Media.

Mahmud. 2011. Metode Penelitian Pendidikan. Bandung: Pustaka Setia Mojares.

OECD. 2014. PISA 2009 \& PISA 2012 Results in Focus Programe for international Student Assesment. Paris: OECD Publishing

Priyatni, E., T. 2010. Membaca sastra dengan ancangan literasi kritis. Jakarta: Bumi aksara.

Sudarsana, U. 2014. Pembinaan Minat Baca. Jakarta: Universitas Terbuka.

Sugiyono. 2015. Metode Penelitian Kuantitatif, Kualitatif dan R\&D. Bandung: Alfabeta. 